\title{
An Analysis of the Justice Values to Legal Protection for Traditional People from Coastal Reclamation Threat in Coastal Areas
}

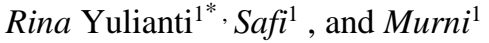 \\ ${ }^{1}$ Faculty of Law, University of Trunojoyo Madura, Madura, Indonesia
}

\begin{abstract}
The background of this research is based on the fact that law protection to the traditional people in coastal areas due to the impacts of coastal reclamation tends to be low. Protection scheme in Law 27/2007 jo Law $1 / 2014$ and its translation rules has not positioned the equality in terms of coastal resources use based on the justice principles. The research method of normative law by using statute approach is employed to see the justice value implementation to grant law protection for traditional people. The current research shows that the setting to coastal reclamation activities by legalizing the compensation method is inadequate to replace and restore their livelihood from generation to generation in the use of natural resources missing due to the adverse impact of given activities. This criterion indicates the stolen honour to people rights. Injustice because of the absence of agreement rights related to coastal reclamation activities potentially breaks the nature of people rights. The introduced regulation lets the fishermen's rights broken, in particular this is due to the objection mechanism and its clear period when the people disagree to reclamation activities are not ruled in the process of reclamation planning.
\end{abstract}

\section{Introduction and literature review}

The adversely impact of the development policies in the coastal areas through the reclamation activities are not only resulting in the change of societies' life style, but also leading to

\footnotetext{
* Corresponding author: rina.yulianti@trunojoyo.ac.id
} 
ecosystem habitat damage. Chapter VI Law No 1 Year 2014 in Article 60 Paragraph (1) rules about rights, obligation, and the people's roles. Their rights associate with coastal area management and small islands. Article 60 Paragraph (1) Law 1/2014 clearly stated that, in the domain of coastal area management and small islands, people's rights refer to:

a. Has an access to parts of coastal waters licensed to both location and management;

b. Propose the fishery areas traditionally into RZWP-3-K;

c. Propose the area of indigenous and tribal people into RZWP-3-K;

d. Manage the coastal natural resources and small islands based on the applied customary law and loyal to legal regulation;

e. Gain the advantages of the coastal area management manifestation and small islands;

f. Be well informed of coastal area management and small islands;

g. Report and complain the loss caused by the implementation of the coastal area management and small islands to the authorities;

h. Express the objection to the announced management planning in a certain period of time;

i. Report the presumption of pollution, and or area destruction and small islands to law enforcers;

j. Report the lawsuit pertaining to the problems of coastal areas and small islands losing their livelihood to the court;

k. Get a compensation; and

1. Obtain legal assistance to the existing problems in managing the coastal areas and small islands in accordance with regulation.

The basic freedom should be equally distributed and must not be victimized for economic purposes.[1] However, the revised Law 1/2014 including the element of the society in proposing the coastal area management planning and small islands equalized with government and business field have disrupted Article 28 Paragraph (2) 1945 Constitution by legalizing the equality between traditional fishermen and private sectors because the subjects are different from very beginning. Indeed, Legislators (the House of Representatives and Ministry of Maritime Affairs and Fisheries) require free competition leading to discrimination to traditional fishermen.

Article 60 paragraph (1) Law 1/2014 mentions the society only indicating people based on the Article 1 Item 32 Law 1/2014 covering the society. It refers to customary law community, local people, and traditional people inhabiting the coastal areas and small islands. The coastal area management criteria closely relate to protection. The fact is that traditional people have low level of law protection. This is because not only the huge number of the traditional population, but also their heavy reliance on the marine resources. Therefore, this study aims to critically analyse the justice values based on legal protection 3 


\section{Objective to study}

The discussing issue in this research is "how do the justice values to legal protection from coastal reclamation threats the areas given for traditional society?"

\section{Methodology}

This research employs the normative law or legal doctrine research method. The applied approach means to address the written rules pertaining to coastal reclamation and societies' constitutional rights in the coastal areas from 1945 Constitution, Law 27/2007, Law 1/2014, and its translation rules. It is also a documentary or library research in the context of normative law research studying the secondary data and other aspects such as theories, philosophy, comparison, structure or composition, consistency, general and specific explanation towards each article, formality, the binding law and law language.

\section{Discussion}

Traditional people as it is stated in Article 35 Law 1/2014 refer to "traditional fishery society that their traditional rights to fishing and other legal activities in a particular region in archipelagic waters is legally recognized in accordance with international maritime law".

The existence of fishermen as traditional people in coastal areas has become the crucial part in the context of livelihood and life sustainability. The current paradigm positioning the multifunction of cities due to reclamation to benefit societies, in most cases, is totally failed in its implementation. Indeed, the complex social and environmental problems as a consequence arise and are downward impossible to resolve.

Article 17 Law Paragraph (2) 1/2014 in its explanation defines "the traditional fishermen whose use the manual boat, work manually from one generation to the next, have fixed fishing areas for their daily needs."[2]

The coastal reclamation activities potentially threat the societies' position particularly the traditional fishermen heavily relied on their livelihood for years from the coastal resources.

The amendment of Law 1/2014 has not shown the standardized criteria of the sustainable livelihood of the people based on the justice principle. The formulation of the Article 32 Paragraph 2 Law 27/2007 is frequently translated as the grant of adequate compensation as a livelihood alternative and is perceived to be able to resolve their economic problems. However, the perception is truly untrue based on the criteria proposed by Constitutional Court, the respect that must be shown to traditional people's right in using the natural resources from generation to generation.

The injustice experienced by traditional people especially the fishermen is also represented in the Presidential Regulation No 122 Year 2012, Article 27 Letter c Presidential 
Regulation 122/2012 clearly stating the criteria for sustainable life and livelihood of the society which, to some extent, legalize the adversely impacts of coastal reclamation. This point is opposite of letter $\mathrm{b}$ which obliges the reclamation activities must be able to preserve the livelihood of the people.

The contrastive explanation towards the criteria of the sustainable life and livelihood of the society in the article formulation 27 the Presidential Regulation 122/2012 is potentially open to interpretation disadvantaging the inhabitants. The compensation previously understood as an adequate compensation goes onto opposite direction because it is unable to replace their livelihood because of reclamation. If it works in this way, the designed criteria violate the respect to people's right in the use of natural resources.

The poor efforts to integrate the developmental programs among sectors through the spatial usage; the small room for development in the process of future plan; failure in accommodating the fast development dynamics; and the lack of the natural resource data and information in the ocean, coastal areas, and small islands underlie the belief that society plays a significant role in the developmental process. Their position signifies more important role because social transformation can work only if they realize their right and obligation and have a capacity to do so. Additionally, they behave according to their role as the subject in the process of developmental acceleration and are a part of decision makers. The result thus puts emphasis on the functions of law facilitating the social engineering through upright law legalization prioritizing the people's interests and their application serves justice to people.

Justice as fairness in a theory of justice, as John Rawls states, constitutionally protects the most advantageous parties in a society, no freedom or welfare exchange with others allowed.[3]

The injustice caused by the uncertainty of rights to agreement of coastal inhabitants especially the traditional fishermen in changing the scheme HP-3 is permissive through two steps. They are licenses to location and management potentially violating the inhabitants' rights. The introduced regulation defies their rights especially the process of reclamation activities such as the objection mechanism and the time allotment what if the people show an objection to the given activities are not ruled further.

The remarkable flora studies in Manado as the city with its massive reclamation indicate that the coastal people's involvement pertaining to the reclamation has not been considered into account. Article 34 Paragraph (2) Law No 27 Year 2007 stated only that the implementation of the reclamation as stated in Paragraph (1) must protect and care of the sustainable life and livelihood of the people. It has no clear statement demonstrating the coastal inhabitants' involvement in reclamation. Therefore, their control to coastal activities is constrained. They work as a labour and a shopkeeper only. To date, their existence is seen as the outsiders, has no right to objection, and consequently their rights are all ignored, as the labour exceptionally. [4]

The Rawls' perspective on justice is based on the prior thought that "all people are well positioned, if its structure is accepted by all as a justice". Rawls develops two political justice 
principles (the past must be explained by the Law; law system, and so on) claimed to be neutral, and therefore they are eligible for everyone regardless their religious, cultural, and political affiliation background. Rawls achieves neutrality based on two assumptions in which they are universal. Firstly, everyone wishes to have their interests guaranteed; Secondly, everyone is rational, not merely emotional, behaves based on their interest.[5]

In the ordered society, having justice resulted from people's genuine consensus to guarantee its distribution and to encourage social cooperation is important. In other words, the procedures should be neutral. It demands the related parties in the process of justice principle selection to be in the original position. Here, all parties must be recognized and threatened as an individual rational, free, having the same rights. They are also assumed as the veil of ignorance. The purpose of this manner is to maximize their efforts to stance the best thing for themselves. In short, the idea is against for justice as fairness. The John Rawls's notion, however, aims to put everyone in the original position to free them from the feeling of envious of other's success.[6]

John Rawls strongly believes that, in the original position, all parties agree and preserve the objectivity based on the justice principles even though they have different moral or rational states. Accordingly, they will be rational to select the two justice principles: the greatest equal liberty principle and the difference principle. John Rawls points the principles out as:[7]

First,each person is to have an equal right to the most extensive basic liberty compatible with a similar liberty for others, Second. social and economic inequalities are to be arranged so that they are both (a) reasonably expected to be everyone's advantage, and (b) attached to positions and offices open to all.

The principles can be further explained: the first positions everyone having the same right to the widest basic freedom, as it is applicable for all. The latter claims that social and economic gaps must be legally ruled as to (a) advantage everyone, (b) all position and power are accessible for everyone.

Regarding to the coastal reclamation, the justice principles proposed by John Rawls are not reflected in the reclamation management pertaining to the issue of sustainable life and livelihood. The greatest equal liberty principle means that everyone has the equal right to all societies' profit. It allows people to orient a personal profit as long as they give benefit to all parties. The reclamation cases in Serangan and Kota Ambon islands can denote in which the capitalist tends to have more room to expand their business that the benefit is not obviously for all, especially the local exerted and consequently, they have to let their land go on behalf of business investment and government's interest for business tax profit purposes.

Article 33 Paragraph (5) on Ministerial regulation KP 28/2014 loosens the reclamation activities to gain more benefit. This is because Article 33 Paragraph (5) allows the capitalist to relocate the ecosystem rehabilitation to the next.

The traditional fishermen are getting more exerted if the relocation becomes an option to reposition the living resources. It apparently indicates that the difference principle proposed 
by John Rawls is not underlying the formulation of Article 33 Paragraph (5) Ministerial Regulation KP 28/2014. The traditional fishermen did not obtain the difference principle and the principle of fair equality of opportunity practically. The social and economic gap conditions should be legally ruled to encourage supportive situation benefitting the weakest society (at least to have equal access to prosperity, income, and authority).

The learning lesson from Rawls' theories, other than justice procedure, is that the law maker must provide sufficient protection to minority, with small access to resources. Fair legal protection for traditional people can be achieved by considering them as small, poor, or weak. Those conditions must be put into consideration in making decision when regulation made.

\section{Conclusion}

The policy makers and law creators have violated the constitutional mandates about the aim of the nation establishment is to increase the public welfare and hold social justice. The unequal position between the traditional society and capitalist shows the nation stance benefitting the capitalist. Indeed, it hinders and retains the sense of social justice embodiment.

The efficiency principle to gain more benefit for small parties should not underlay the coastal area management. However, it is supposed to prioritize the social justice interest. Therefore, its management addressed to protect, conserve, rehabilitate, use, and enrich the coastal resources and small islands, and their sustainable ecological system.

\section{References}

1. K. Lebacqs, Six Theory Of Justice, (Indianapolis :Augsbung Publishing House : 1986), diterjemahkan Y. Santoso, Teori-TeoriKeadilan, (Bandung : Nusa Media, 2014).

3. See explanation of Article 17 Paragraph (2) Law 1/2014

4. J. Rawls, A Theory of Justice, (Cambridge : Harvard University Press , 1995, translated by Uzair fauzan\&Heru, Teori Keadilan - Dasar - Dasar Filsafat Politik Untuk Mewujudkan Kesejahteraan Sosial Dalam Negara, (Yogyakarta : Pustaka Pelajar cetakan II, 2011).

5. PricillaKalalo in her Disertation, 2008, reported that reclamation policies in Manado, North Sulawesi, just allow people to labour.

6-7 J. Rawls, A Theory of Justice, (Cambridge : Harvard University Press , 1995, translated by Uzair fauzan\&Heru, Teori Keadilan - Dasar - Dasar Filsafat Politik Untuk Mewujudkan Kesejahteraan Sosial Dalam Negara, (Yogyakarta : Pustaka Pelajar cetakan II, 2011). 


\section{Acknowledgments}

We gratefully thank to ministry of research, technology and higher education of the republic of Indonesia for funding this research. 